\section{JURNAL EKONOMI EFEKTIF}

ISSN : $2622-8882$, E-ISSN : 2622-9935

Jurnal Ekonomi Efektif, Vol. 3, No. 3, April 2021

@Prodi Manajemen Fakultas Ekonomi Universitas

Pamulang

\title{
PENGARUH TOTAL HUTANG TERHADAP RENTABILITAS MODAL SENDIRI PADA PT. ACE HARDWARE INDONESIA, TBK PERIODE TAHUN 2012-2019
}

\author{
Yeti Kusmawati \\ Universitas Pamulang, Tangerang Selatan, Banten, Indonesia \\ dosen02619@unpam.ac.id
}

Manuskrip: Feb-2021 Ditinjau: Mar-2021; Diterima: Mar-2021; Online: Apr-2021; Diterbitkan: Apr-2021

\begin{abstract}
ABSTRAK
Penelitian ini bertujuan untuk mengetahui pengaruh Total hutang terhadap Rentabilitas modal sendiri pada PT. Ace Hardware Indonesia, Tbk Periode Tahun 2012-2019. Metode yang digunakan adalah explanatory research. Teknik analisis menggunakan analisis statistik dengan pengujian regresi, korelasi, determinasi dan uji hipotesis. Hasil penelitian ini variabel Total hutang diperoleh nilai rata-rata sebesar 461,121 milyar. Variabel Rentabilitas modal sendiri diperoleh nilai rata-rata $9,905 \%$. Total hutang berpengaruh positif dan signifikan terhadap Rentabilitas modal sendiri dengan nilai persamaan regresi $\mathrm{Y}=4,597+0,012 \mathrm{X}$, dan nilai koefisien korelasi 0,924 atau memiliki tingkat hubungan sangat kuat dengan nilai determinasi $85,3 \%$. Uji hipotesis diperoleh signifikansi $0,000<0,05$.
\end{abstract}

\section{Kata Kunci: Total Hutang, Rentabilitas Modal Sendiri.}

\section{ABSTRACT}

This study aims to determine the effect of total debt on equity profitability at PT. Ace Hardware Indonesia, Tbk for the period 2012-2019. The method used is explanatory research. The analysis technique uses statistical analysis with regression testing, correlation, determination and hypothesis testing. The results of this research variable Total debt obtained an average value of 461,121 billion. The profitability variable of own capital obtained an average value of $9.905 \%$. Total debt has a positive and significant effect on equity profitability with the regression equation value $Y=4.597+0.012 X$, and the correlation coefficient value is 0.924 or has a very strong level of relationship with a determination value of $85.3 \%$. Hypothesis testing obtained a significance of $0.000<0.05$.

\section{Keywords: Total Debt, Own Capital Rentability.}




\section{PENDAHULUAN}

\section{A. Latar Belakang Masalah}

Pengembangan ekonomi yang dilakukan pemerintah sekarang ini tidak lagi bertujuan untuk mempercepat laju pertumbuhan ekonomi, laju pertumbuhan ekonomi bisa dilakukan dengan pencapaian usaha. Dengan berkembangnya dunia usaha yang semakin pesat ini, menimbulkan permasalahan yang dihadapi, sehingga tidak sedikit perusahaan yang mengalami kegagalan karena tidak mampu bersaing. Dalam menjalankan usahanya setiap perusahaan dihadapi dengan berbagai aktifitas untuk kegiatan operasionalnya.

Dalam mencapai tujuan perusahaan yaitu memaksimalkan nilai perusahaan untuk memakmurkan para pemegang saham dan para karyawannya, para manajer perusahaan harus mampu mengantisipasi segala perubahan situasi baik yang ada di dalam perusahaan maupun di luar perusahaan yang dapat mempengaruhi jalannya perusahaan. Dalam menjalankan usahanya, manajer perusahaan tidak akan terlepas dari masalah hutang perusahaan yaitu hutang jangka panjang maupun hutang jangka pendek. Bahkan apabila perusahaan telah mencapai posisi tertentu yang cukup baik sesuai dengan tujuan, maka perusahaan tersebut dapat melakukan perluasan usaha. Dalam melakukan perluasan usaha, suatu perusahaan tidak akan lepas dari kebutuhan akan modal yang bisa diperoleh dari hutang.

Pendirian suatu usaha atau badan hukum perusahaan, haruslah memenuhi persyaratan yang telah di tetapkan, keleluasaan beraktifitas adalah pertimbangan tentang luasnya bidang usaha yang akan dimasuki oleh pemiliknya, misalnya tanpa dibatasi oleh modal.

Untuk menjalankan kegiatan operasionalnya perusahaan membutuhkan dana yang cukup besar agar perusahaan dapat berjalan dengan lancar. Dana yang dikeluarkan dapat berupa modal sendiri juga dari sumber dana dan pihak lain yakni berupa modal asing. Untuk menjalankan kegiatan operasionalnya perusahaan bisa menggunakan modal sendiri tetapi untuk menjalankan kegiatan operasional yang bertujuan untuk perluasan investasi baik jangka pendek maupun jangka panjang suatu perusahaan akan dihadapkan dengan keputusan penambahan dana berupa modal asing.

Dengan adanya modal tambahan dana berupa modal asing baik hutang jangka pendek maupun hutang jangka panjang diharapkan perusahaan dapat menjaga eksistensinya dan harus siap dengan permasalahan yang muncul dalam perusahaannya. Manajemen perusahaan akan selalu dihadapkan dengan suatu keputusan yang berkaitan dengan penambahan dana, dengan tujuan untuk meningkatkan keuntungan yang lebih baik dari sebelumnya. Perkembangan dan pertumbuhan adalah suatu yang selalu menjadi perhatian utama bagi manajemen dalam mengelola usahanya, karena selain salah satu merupakan cara yang efektif dalam mempertahankan hidup perusahaan dalam lingkungan yang cepat berubah. Sehubungan dengan itu, pada umumnya setiap perusahaan telah mempersiapkan perencanaan yang sistematis untuk dapat mengendalikan sumber dananya untuk mencapai pertumbuhan dan perkembangan yang diharapkan. Total Hutang adalah seluruh total hutang perusahaan baik hutang jangka pendek maupun hutang jangka panjang dalam suatu periode akuntansi. Semakin tinggi total hutang ini menunjukkan perusahaan semakin beresiko. Hutang jangka pendek merupakan kewajiban perusahaan pada pihak lain yang harus dipenuhi dalam jangka waktu satu tahun atau hutang yang jatuh temponya masuk siklus akuntansi yang sedang berjalan.

Hutang jangka panjang merupakan kewajiban perusahaan kepada pihak lain yang harus dipenuhi atau hutang yang jatuh temponya lebih dari satu tahun. Rentabilitas 
merupakan alat yang digunakan untuk mengukur kemampuan perusahaan untuk menghasilkan laba dengan semua modal yang bekerja didalamnya, rentabilitas terbagi ke dalam dua macam rentabilitas, yaitu rentabilitas ekonomi dan rentabilitas modal sendiri.

Rentabilitas ekonomi pengertiannya sama seperti rentabilitas secara umum yaitu untuk menghasilkan laba dengan modal sendiri, perbedaannya adalah pada rentabilitas ekonomi, karena yang bekerja adalah semua modal (modal asing dan modal sendiri) sedangkan rentabilitas modal sendiri karena yang bekerja adalah hanya modal sendiri, maka yang dibagi adalah laba pemegang saham yakni laba setelah pajak.

Untuk mencapai perusahaan dengan melihat tingkat dana yang besar belum merupakan ukuran bahwa perusahaan tersebut telah bekerja secara efisien untuk menghasilkan laba atau dengan kata lain mengukur efisensi itu dengan menghitung rentabilitas. Dimana perusahaan mengharapkan rentabilitas yang maksimal. Rentabilitas sering diartikan sebagai suatu perusahaan dengan seluruh modal yang bekerja didalamnya untuk menghasilkan laba.

Didirikan pada tahun 1995 sebagai anak perusahaan dari PT. Kawan Lama Sejahtera - pusat perlengkapan teknik dan industri 1 di Indonesia, PT. Ace Hardware Indonesia, Tbk. ialah pemegang lisensi tunggal Ace Hardware di negeri ini, yang ditunjuk secara langsung oleh Ace Hardware Corporation, Amerika.

Komitmen Ace Hardware Indonesia dalam memberikan kemudahan dan kepuasan kepada pelanggan juga didukung dengan tersedianya pembelanjaan secara online. Saat ini kita dapat menikmati kemudahan berbelanja berbagai produk Ace Hardware dengan praktis, mudah dan cepat secara online melalui ruparupa.com selaku anak perusahaan dari PT Kawan Lama Sejahtera.

Berdasarkan latar belakang diatas, maka penulis tertarik untuk melakukan penelitian dalam skripsi yang berjudul "Pengaruh Total Hutang Terhadap Rentabilitas Modal Sendiri Pada PT. Ace Hardware Indonesia, Tbk"

\section{B. Rumusan Masalah}

1. Bagaimana Total hutang pada pada PT. Ace Hardware Indonesia, Tbk Periode Tahun 2012-2019?.

2. Bagaimana Rentabilitas modal sendiri pada PT. Ace Hardware Indonesia, Tbk Periode Tahun 2012-2019?.

3. Adakah pengaruh antara Total hutang terhadap Rentabilitas modal sendiri pada PT. Ace Hardware Indonesia, Tbk Periode Tahun 2012-2019?.

\section{Tujuan Penelitian}

1. Untuk mengetahui kondisi Total hutang pada PT. Ace Hardware Indonesia, Tbk Periode Tahun 2012-2019.

2. Untuk mengetahui kondisi Rentabilitas modal sendiri pada PT. Ace Hardware Indonesia, Tbk Periode Tahun 2012-2019.

3. Untuk mengetahui pengaruh antara Total hutang terhadap Rentabilitas modal sendiri pada PT. Ace Hardware Indonesia, Tbk Periode Tahun 2012-2019.

\section{METODE PENELITIAN}

\section{Populasi}

Populasi dalam penelitian ini laporan keuangan PT. Ace Hardware Indonesia, Tbk Periode Tahun 2012-2019 selama 5 tahun

\section{Sampel}

Teknik pengambilan sampling dalam penelitian ini adalah samplel jenuh, dimana 
semua anggota populasi dijadikan sebagai sampel. Dengan demikian sampel dalam penelitian ini laporan keuangan PT. Ace Hardware Indonesia, Tbk Periode Tahun 20122019 selama 5 tahun.

\section{Jenis Penelitian}

Jenis penelitian yang dipakai adalah asosiatif, dimana tujuannya adalah untuk mengetahui mencari keterhubungan antara variabel independen terhadap variabel dependennya

\section{Metode Analisis Data}

Dalam menganalisis data digunakan uji validitas, uji reliabilitas, analisis regresi linier sederhana, koefisien korelasi, koefisien determinasi dan uji hipotesis.

\section{HASIL PENELITIAN DAN PEMBAHASAN}

\section{Analisis Deskriptif}

Pada pengujian ini digunakan untuk mengetahui skor minimum dan maksimum skor tertinggi, ratting score dan standar deviasi dari masing-masing variabel. Adapun hasilnya sebagai berikut:

Tabel 1. Hasil Analisis Descriptive Statistics

\section{Descriptive Statistics}

\begin{tabular}{lr|r|r|r|r} 
& N & Minimum & Maximum & \multicolumn{1}{c}{ Mean } & \multicolumn{1}{c}{ Std. Deviation } \\
\hline Total hutang (X) & 8 & 219.9 & 638.7 & 461.121 & 158.0110 \\
\hline Rentabilitas modal sendiri (Y) & 8 & 5.8 & 12.2 & 9.905 & 1.9691 \\
\hline Valid N (listwise) & 8 & & & & \\
\hline
\end{tabular}

Total hutang diperoleh nilai minimum sebesar 219,9 dan nilai maximum 638,7 dengan rata-rata sebesar 461,121 dengan standar deviasi 158,011.

Rentabilitas modal sendiri diperoleh nilai minimum sebesar 5,8 dan nilai maximum 12,2 dengan rata-rata sebesar 9,905 dengan standar deviasi 1,969.

\section{Analisis Verifikatif.}

Pada analisis ini dimaksudkan untuk mengetahui pengaruh variabel independen terhadap variabel dependen. Adapun hasil pengujian sebagai berikut:

\section{a. Analisis Regresi Linier Sederhana}

Uji regresi ini dimaksudkan untuk mengetahui perubahan variabel dependen jika variabel independen mengalami perubahan. Adapun hasil pengujiannya sebagai berikut:

Tabel 2. Hasil Pengujian Regresi Linier Sederhana

\section{Coefficients $^{\mathrm{a}}$}

\begin{tabular}{lr|r|r|r|r} 
& \multicolumn{2}{c}{$\begin{array}{c}\text { Unstandardized } \\
\text { Coefficients }\end{array}$} & $\begin{array}{l}\text { Standardized } \\
\text { Coefficients }\end{array}$ & & \\
Model & \multicolumn{1}{c|}{$\begin{array}{c}\text { Coefficients } \\
\text { B }\end{array}$} & Std. Error & Beta & t & \multicolumn{1}{c}{ Sig. } \\
\hline 1 (Constant) & 4.597 & .944 & & 4.869 & .003 \\
\hline Total hutang $(\mathrm{X})$ & .012 & .002 & .924 & 5.903 & .001 \\
\hline
\end{tabular}

Berdasarkan hasil pengujian pada tabel di atas, diperoleh persamaan regresi $\mathrm{Y}$ $=4,597+0,012 X$. Dari persamaan tersebut dijelaskan sebagai berikut:

1) Konstanta sebesar 4,597 diartikan jika Total hutang tidak ada, maka telah terdapat nilai Rentabilitas modal sendiri sebesar 4,597 point.

2) Koefisien regresi Total hutang sebesar 0,012 , angka ini positif artinya setiap ada peningkatan Total hutang sebesar 0,012 point maka Rentabilitas modal sendiri juga akan mengalami peningkatan sebesar 0,012 point. 


\section{b. Analisis Koefisien Korelasi}

Analisis koefisien korelasi dimaksudkan untuk mengetahui tingkat kekuatan hubungan dari variabel independen terhadap variabel dependen baik secara parsial maupun simultan. Adapun hasil pengujian sebagai berikut:

Tabel 3. Hasil Pengujian Koefisien Korelasi Total hutang Terhadap Rentabilitas modal sendiri.

\section{Correlations $^{\mathrm{b}}$}

\begin{tabular}{ll|r|r} 
& & $\begin{array}{c}\text { Total hutang } \\
(\mathrm{X} 1)\end{array}$ & \multicolumn{2}{c}{$\begin{array}{c}\text { Rentabilitas modal } \\
\text { sendiri (Y) }\end{array}$} \\
\hline Total hutang (X) & Pearson Correlation & 1 & $.924^{* *}$ \\
\cline { 2 - 4 } & Sig. (2-tailed) & & .001 \\
\hline $\begin{array}{l}\text { Rentabilitas modal } \\
\text { sendiri (Y) }\end{array}$ & Pearson Correlation & $.924^{* *}$ & 1 \\
\cline { 2 - 4 } & Sig. (2-tailed) & .001 & \\
\hline
\end{tabular}

Berdasarkan hasil pengujian diperoleh nilai korelasi sebesar 0,924 artinya Total hutang memiliki hubungan sangat kuat terhadap Rentabilitas modal sendiri.

\section{c. Analisis Koefisien Determinasi}

Analisis koefisien determinasi dimaksudkan untuk mengetahui besarnya persentase pengaruh dari variabel independen terhadap variabel dependen. Adapun hasil pengujian sebagai berikut:

Tabel 4. Hasil Pengujian Koefisien Determinasi Total hutang Terhadap Rentabilitas modal sendiri.

\section{Model Summary}

\begin{tabular}{ll|l|l|l} 
Model & R & R Square & Adjusted R Square & Std. Error of the Estimate
\end{tabular}

\begin{tabular}{lrrrr}
\hline 1 & $.924^{\mathrm{a}}$ & .853 & .829 & .8152 \\
\hline
\end{tabular}

Berdasarkan hasil pengujian diperoleh nilai determinasi sebesar 0,853 artinya Total hutang memiliki kontribusi pengaruh sebesar 85,3\% terhadap Rentabilitas modal sendiri.

\section{d. Uji Hipotesis}

Pengujian hipotesis dengan uji t digunakan untuk mengetahui hipotesis mana yang diterima.

Rumusan hipotesis: Terdapat pengaruh yang signifikan antara Total hutang terhadap Rentabilitas modal sendiri.

Tabel 5. Hasil Uji Hipotesis Total hutang Terhadap Rentabilitas modal sendiri.

\section{Coefficients $^{\mathrm{a}}$}

Unstandardized Standardized

Coefficients Coefficients

\begin{tabular}{ll|r|c|c|c} 
Model & B & Std. Error & Beta & t & Sig. \\
\hline 1 (Constant $)$ & 4.597 & .944 & & 4.869 & .003
\end{tabular}

Berdasarkan hasil pengujian pada tabel di atas, diperoleh nilai t hitung $>\mathrm{t}$ tabel atau $(5,903>2,447)$, dengan demikian hipotesis yang diajukan bahwa terdapat pengaruh yang signifikan atara Total hutang terhadap Rentabilitas modal sendiri diterima.

\section{PEMBAHASAN HASIL PENELITIAN}

\section{Kondisi Jawaban Responden Variabel Total hutang}

Berdasarkan data empiris dan analisis data, variabel Total hutang diperoleh nilai rata-rata per tahun sebesar 461,121 miluar. 


\section{Kondisi Jawaban Responden Variabel Rentabilitas modal sendiri}

Berdasarkan data empiris dan analisis data, variabel Rentabilitas modal sendiri diperoleh nilai rata-rata per tahun sebesar $9,905 \%$.

\section{Pengaruh Total hutang Terhadap Rentabilitas modal sendiri}

Total hutang berpengaruh signifikan terhadap Rentabilitas modal sendiri dengan persamaan regresi $\mathrm{Y}=4,597+0,012 \mathrm{X}$, nilai korelasi sebesar 0,924 atau memiliki hubungan sangat kuat dengan kontribusi pengaruh sebesar 85,3\%. Pengujian hipotesis diperoleh nilai $t$ hitung $>\mathrm{t}$ tabel atau $(5,903>2,447)$. Dengan demikian hipotesis yang diajukan bahwa terdapat berpengaruh signifikan antara Total hutang terhadap Rentabilitas modal sendiri diterima.

\section{PENUTUP}

\section{Kesimpulan}

a. Kondisi variabel Total hutang berdasar pada periode laporan keuangan 5 tahun diperoleh Total hutang rata-rata sebesar 461,121.

b. Kondisi variabel Rentabilitas modal sendiri berdasar pada periode laporan keuangan 5 tahun diperoleh Total hutang rata-rata sebesar 9,905.

c. Total hutang berpengaruh signifikan terhadap Rentabilitas modal sendiri dengan persamaan regresi $\mathrm{Y}=4,597+0,012 \mathrm{X}$, nilai korelasi sebesar 0,924 atau kuat dan kontribusi pengaruh sebesar $85,3 \%$ sedangkan sisanya sebesar $57,9 \%$ dipengaruhi faktor lain. Uji hipotesis diperoleh nilai t hitung > t tabel atau $(5,903>2,447)$.

\section{Saran}

a. Pada dasarnya hutang dalam perusahaan merupakan salah satu modal utama dalam menjalani suatu aktifitas bisnis. Besarnya hutang harus diimbangi dengan pendapatan yang lebih besar dibanding hutang tersebut, maka perusahaan akan dikatakan sehat apabila hutang yang dimiliki lebih kecil dibanding modal perusahaan.

b. Dalam meningkatkan besar rentabilitas, sebaiknya perusahaan menentukan pilihan penggunaan modal baik modal sendiri maupun modal asing dengan se- efektif dan seefisien mungkin, meminimalisir biaya, mengatur penggunaan dana dan pembiayaan operasi dimasa yang akan datang.

c. Dalam melakukan tambahan modal, lebih baik perusahaan menggunakan modal sendiri lebih besar dibanding modal asing yang berada di saham perusahaan, karena modal asing yang tinggi dapat mempengaruhi keputusan yang diambil pada rapat pemegang saham.

\section{DAFTAR PUSTAKA}

Agus Harjito \& Martono, (2010) "Manajemen Keuangan” Yogyakarta: Penerbit Ekonisia. Agus Sartono. (2010). "Manajemen Keuangan Toeri dan Aplikasi”, Edisi keempat, Yogyakarta: Penerbit BPFE.

Algifari. (2015). “Analisis Regresi untuk Bisnis dan Ekonomi”. Yogyakarta: BPFE.

Amelia, R. W., \& Sunarsi, D. (2020). Pengaruh Return On Asset Dan Return On Equity Terhadap Debt To Equity Ratio Pada PT. Kalbe Farma, TBK. Ad-Deenar: Jurnal Ekonomi dan Bisnis Islam, 4(01), 105-114.

Arikunto, Suharsimi (2014). "Prosedur Penelitian Suatu Pendekatan Praktek". Jakarta: Rineka Cipta.

Bambang Riyanto, (2011). "Dasar-dasar Pembelanjaan Perusahaan". Edisi ke empat, BPFE Yogyakarta. 
Fahmi, Irham (2012), "Pengantar Manajemen Keuangan" Cetakan pertama. Bandung: Penerbit Alfabeta.

Imam Ghozali (2017). “Aplikasi Analisis Multivariate Dengan Program SPSS”. Edisi Kelima. Semarang: Badan Penerbit Undip.

Istijanto (2014) "Riset Sumber Daya Manusia". Jakarta: PT. Gramedia Pustaka

Jasmani, J. (2018). Pengaruh Kinerja Keuangan Terhadap Harga Saham (Analisis Pada Perusahaan Property dan Real Estate Yang Go Public di Bursa Efek Indonesia. Jurnal Akuntansi Indonesia, 12(2).

Jasmani, J. (2019). The Effect of Liquidity and Working Capital Turnover on Profitability at PT. Sumber Cipta Multiniaga, South Jakarta. PINISI Discretion Review, 3(1), 2938.

Kasmir (2010), “Analisis Laporan keuangan”, penerbit raja grafindo persada, Jakarta

Kasmir, (2010). "Pengantar Manajemen Keuangan", Edisi Pertama, Cetakan kedua, Jakarta: Penerbit Prenada Media.

Kasmir. (2012) "Pengantar Manajemen Keuangan", Edisi Pertama, Cetakan kedua, Jakarta: Prenada Media.

Kharis, Ismu Fadli (2011). "Studi Mengenai Impulse Buying dalam Penjualan Online". Semarang : Skripsi Universitas Diponegoro

Martono dan Agus Harjito, (2011). "Manajemen Keuangan", Jakarta: Penerbit Ekonisia.

Munawir (2010), “Analisis Laporan Keuangan”, Edisi Ke Empat, Penerbit Liberty, Yogyakarta.

Nofiana, L., \& Sunarsi, D. (2020). The Influence of Inventory Round Ratio and Activities Round Ratio of Profitability (ROI). JASa (Jurnal Akuntansi, Audit dan Sistem Informasi Akuntansi), 4(1), 95-103.

Nurjaya, N., Affandi, A., Erlangga, H., Sunarsi, D., \& Jasmani, J. (2021). The Effect of Product Promotion and Innovation Activities on Marketing Performance in Middle Small Micro Enterprises in Cianjur. Budapest International Research and Critics Institute (BIRCI-Journal): Humanities and Social Sciences, 4(1), 528-540.

Nuryani, Y., \& Sunarsi, D. (2020). The Effect of Current Ratio and Debt to Equity Ratio on Deviding Growth. JASa (Jurnal Akuntansi, Audit dan Sistem Informasi Akuntansi), 4(2), 304-312.

Santoso, Singgih (2015). “Menguasai Statistik Multivariat”. Jakarta: PT Elex Media Komputindo.

Sartono, "Manajemen Keuangan Aplikasi Dan Teori", Edisi Keempat, BPFE, Yogyakarta, 2008.

Sawir, (2003). "Analisis Kinerja Keuangan dan Perencanaan Keuangan Perusahaan", Cetakan ketiga, Jakarta: Penerbit PT. Gramedia Pustaka Utama.

Sugiyarso, G. dan F. Winarni, "Manajemen Keuangan (Pemahaman Laporan Keuangan, Pengelolaan Aktiva, Kewajiban dan Modal serta Pengukuran

Sugiyono (2017), "Metode Penelitian Administrasi : dilengkapi dengan Metode R \& D". Bandung: Alfabeta.

Sulastri, L., Novitasari, D., Rahmaningtyas, W., Sulaeman, R., \& Erlangga, H. (2020). The Role of Decision Support System and Risk Management Using Social Media Promotion. International Journal of Psychosocial Rehabilitation, 24(1). 